\title{
COVID-19- Its Impact on Poultry Industry in India
}

\section{M.Nazeeruddin}

\begin{abstract}
The outbreak of the COVID-19 is affecting more than 3 Lakh confirmed cases from 180 countries and territories around the world. It is said to be that nearly 341 confirmed cases have been reported in India as of March 22,2020 . Normally the Corona Virus would be found in animals and can be transmitted from animals to human beings and then spread from person to person. The COVID-19 is getting by humans contact with animals. Poultry industry is one of the fastest growing and most profitable industries in India it is also an integral part of agricultural sectors. According to the recent surveys that about 3 million farmers and 15 million agrarian farmers are employed in the poultry industry and it has contributed around Rs 26000 crore to the national income. Such a fast growing industry is now temporarily facing neck deep financial crises for the past one month due to COVID-19.

Keywords: COVID-19, Indian Economy ,Resource based industry and Poultry Industry.
\end{abstract}

\section{INTRODUCTION}

Poultry industry belongs to resource based industry which are started near location viz., agro based, forest product, live-stock, fish, marine, poultry, leather and mineral products. It is one of the major profitable industry for the entrepreneurs. It provides employment to millions of people across the country. Further, it is hugely contributing to national income. This industry never dries up, but in recent times it is earning huge loss due to COVID-19. The outbreak of COVID-19 has rattled the entire world and adversely effecting the economic growth in general all over the world and more particularly the poultry industry in India.

\section{REVIEW OF LITERATURE}

A brief review of the finding of studies on poultry industry in India are presented here under

1.Dr.M. Nazeeruddin works on industrialization and economic development says "the main objective of industrialization programme is to raise the standard of the living of the people. This means industrialization to be sound at a balance development of agriculture and manufacturing industry. Most of the economists spinned their emphasis on one or the other factors viz., low level of technological skills, low level of capital formations and dearth of natural resources , disproportionate growth in population to be responsible for the low level of industrialization.

Revised Manuscript Received on April 15, 2020.

* Correspondence Author

Dr.M. Nazeeruddin,Economics*, Osmania College ,Kurnool,India. Email:xyz1@blueeyesintlligence.org

(c) The Authors. Published by Blue Eyes Intelligence Engineering and Sciences Publication (BEIESP). This is an open access article under the CC BY-NC-ND license (http://creativecommons.org/licenses/by-nc-nd/4.0/)
2. The study of Dr.M.Nazeeruddin on resource based industries in Rayalaseema region, Resource based industries are started around the location of the available natural resources , they are namely agro based, forest product, live stock products(fish,marine,poultry) leather and mineral products.

3. The work of R Mehta and RG Nambier on the poultry industry in India, throws light on the major success story of the poultry industry in India. While agricultural production has been rising at the rate around $2 \%$ per annum, the poultry production has been rising at around 8\% per annum.

4. R Prabhakaran in his study, on Indian poultry industry speaks the poultry industry in India is one of the important contributors to the economy of rural and semi-urban India.

\section{OBJECTIVES OF THE STUDY}

1. To gauge the effect of industrialization on the economic growth.

2. To study the COVID-19 -its impact on poultry industry.

3. To identify the forces which retards greater pace of poultry industry.

4. To suggest suitable measures on how to rescue the industry in the present situation.

\section{METHODOLOGY}

This paper largely relies on secondary sources. Data and information for the present study have been collected from daily news paper THE HINDU,and web sources like familydoctor.org,

www.worldometers.info,https://www.indianmirrior.compoul tryTherefore, the paper relates to the present situations. Hence, data collected from the present studies.

\section{A. Corona Virus}

The outbreak of the COVID-19 is affecting more than 3 lakh confirmed cases from 180 countries and territories around the world. It is said to be that nearly 341 confirmed cases have been reported in India as of March 22, 2020. An outbreak of the corona virus is now called COVID-19 has shaken the entire world and creating problems for the policy makers. It is believed that, it has come from sea food and meat market in Wuhan of China in the month of December 2019. Since then it spreads to all over the world._Normally the Corona Virus would be found in animals and can be transmitted from animals to human beings and then spread from person to person.

Published By:

Blue Eyes Intelligence Engineering

\& Sciences Publication

(C) Copyright: All rights reserved.

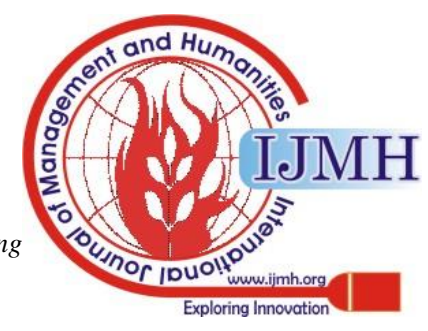




\section{b. Symptoms of Corona Virus:}

COVID-19 symptoms may cause fever, Cough and shortness of breath. It weakened the entire the immune systems of the humans and caused or turned in to like pneumonia or bronchitis. So far, most of the cases are found in adults and some in children have been infected.

The COVID-19 is getting by humans contact with animals. Then it can spread from person to person. It is yet to be found that which animal has caused COVID-19. It is said to be that the COVID-19 virus can be spread through contact with certain bodily fluids, such as droplets in a cough. It might also be caused by touching something an infected person has touch and then touching your hand to your mouth, nose or eyes.

\section{Poultry Industry In India}

Industries are classified into 2 categories.1.) Resource based industries namely agro-based, forest product, live-stock products(fish, marine, poultry)leather and mineral products. 2) Demand based industries viz., metal and metallurgical, chemical and allied industries, textile products, electrical and electronic products and miscellaneous. So poultry industry belongs to resource based industry. Therefore, it is one of the fastest growing and most profitable industries in India. It is also an integral part of agricultural sector. As the production of agriculture has been raising at a rate of 1.5 to 2 percent per year. On the other hand the production of eggs and broilers has also been increasing at a rate of 8 to 10 percent per year. India is the $5^{\text {th }}$ largest egg producers and the $18^{\text {th }}$ largest producer of broilers in the world. The main reason for the fast growing poultry industry is the increase in per capita income, expansion of urbanization and change of tastes and habits of the individuals. Therefore, major population would prefer to go for non vegetarian instead of vegetarian. According to the recent surveys that nearly 3 million farmers and 15 million agrarian farmers are employed in the poultry industry and it has contributed around Rs 26000 crore to the national income.

\section{VI.COVID-19- Its impact on Poultry industry}

According to trade experts that the Indian poultry industry has been growing at much faster pace, along with other industries in India. Such a fast growing industry is now temporarily facing financial crises for the past one month due to COVID-19. The eggs and chicken prices all over the country have been virtually crashed from Rs 180 a kg to Rs $50 \mathrm{a} \mathrm{kg}$. Further, The sales of the poultry products has been standstill. There is a strong misconception among the people that consuming of chicken, they will be contracted with the COVID-19 disease. For that reason most of the consumers are literally staying away from consuming of eggs and chicken. In fact the central government and the state governments have taken several preventive measures to tackle the COVID-19 and try to bring awareness among the people that eggs and chickens would not cause COVID-19.

According to the recent reports that most of the poultry industries in India are getting huge loss due to COVID-19. Further, it is said to be that every day the poultry industry is loosing crores of rupees due to low consumption of eggs and chicken. Actually there is no direct link between chicken and the virus. Even then people are staying away from poultry products. So, as long as the fear is there among the people, it carries big impact on the Indian economy in general and more particularly poultry industry. Because of COVID-19 for the past few days the revenues of the poultry industry has come down and it adversely effecting the growth of the industry. Further, the poultry business has been collapsed and farmers are suffering huge loss. It is said to be that in Tamil-Nadu state alone has suffered nearly 600 crore loss for the past one month. Therefore, the union government and the state government should extend financial support to the poultry industry and rescue them from financial crises.

\section{RESULT OF THE STUDY}

The findings of the paper is that, right now due to COVID-19 the poultry industry in India temporarily facing huge loss. Because, there is a misconception that the consumption of eggs and chicken may cause COVID-19. If the misconception would be removed from the minds of the people, then the industry will come to its normal position. Though, the government is bringing awareness among the people that poultry products will not cause COVID-19.

\section{CONCLUSION}

The poultry industry is fast growing industry in India, is now temporarily facing financial crises for the past one month due to COVID-19. So the union government and the state government should announced financial support to the temporarily sick poultry industries and rescue them from huge loss. The industry which is significantly contributing to the national income and provides employment to millions of peoples across the country and should be bailed out from the crises. The need of the hour is, government should announce that there is no directly link between chicken and COVID-19. Besides, the government authorities should educate the people that consuming of eggs and chicken will not cause COVID-19.

\section{REFERENCES}

1. Industrialization and economic development by Dr.M.Nazeeruddin IJHSSR volume 5, issue 5, page no:26 on November- Dec 2019.

2. Resource Based Industries in Rayalaseema region by Dr.M.Nazeeruddin published in 2020,page no:86,books.google

3. Demand Based Industries in Rayalaseema region by Dr.M.Nazeeruddin published in 2020,page no:87,books.google

4. The poultry industry in India by R Mehta, RG Nambier, 2007.fao.org

5. Indian poultry industry by R Prabhakaran 2014-krishikosh.egranthac.in.

6. Family doctor. Org

7. https://www.worldometers.info

8. https://www.indianmirrior.compoultry

9. Egg, broiler prices slump - The Hindu published on $21^{\text {st }}$ of March 2020

\section{AUTHORS PROFILE}

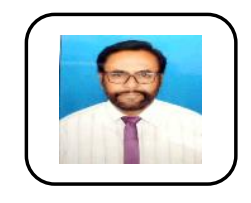

Dr.M. Nazeeruddin was born in 1963 in Anantapur of Andhra Pradesh. He obtained M.A(Economics) in 1985 , M.Phil degree(degree in Economics) in 1989 and Doctor of Philosophy degree in Economics in the year 1994 under the supervision of Prof.K.Nageswar Rao from Sri Krishna Devaraya University, Anantapur. His Ph.d thesis titled "Industrialization and Regional Development" (A study of Large and Medium scale Industries in Rayalaseema Region) is a comprehensive piece of research work covering various issues relating to large and medium scale industries in Rayalaseema Region. A thesis is considered as useful edition in the field of industrial economics. 
He joined the Department of Economics at Osmania College as a lecturer in the year 1992 and became Reader of Economics. He is serving as Head of the Department of Economics and Chairman of Board of Studies in Economics , Osmania College, Kurnool.

Dr.M.Nazeeruddin attended and presented papers at national and international seminars. He has presented nearly 30 papers in national seminars and 4 books to his credit. He has also organised national seminar on "Agricultural Finance in India" and state level seminar on

"Globalization" under the auspices of the Department of Economics, Osmania College, Kurnool. With the financial support of the University Grants commission , New Delhi, he has completed a minor research project on "Industrial sickness" in Kurnool district. Prior to his joining in the Department of Economics, Osmania College, as lecturer, he worked as Research Associate in the Centre of Planning and Development Studies (CPDS), further he worked as Senior Research Associate in a major project at Sri Krishna Devaraya University, Anantapur.

He has been serving in the premier institution Osmania College, Kurnool, for the past 27 years which was conferred twice as A-grade by NAAC. He is Subject Expert and nominated as Member, Board of Studies in many (Autonomous) colleges of Rayalaseema region and also Examiner and Question papers setter for S.K University, Anantapur, Yogi Vemana University, Kadapa and Rayalaseema University, Kurnool . He has good academic publications in both national and international journals to his credit. He earned good name as teacher and also assisting the college administration in different capacities for the past several years. He is currently holding NIRF, NAAC Criteria I co-ordinator and co-ordinator for many more committees. 